\title{
AfCFTA's Notification Options to WTO: Enabling Clause or Article XXIV Exception
}

DOI http://dx.doi.org/10.4314/mlr.v14i2.7

\section{Abstract}

Yehualashet Tamiru Tegegn *

Since the formation of the Organization of African Unity (OAU), African countries envisage regional integration to enhance trade among themselves. This effort was preceded by the formation of the sub-regional economic groups which serve as building blocks towards a larger integration. Africa Continental Free Trade Agreement (hereinafter AfCFTA) came into force in May 2019. As per the procedural requirements of the WTO, AfCFTA should be notified either to WTO's Committee on Trade and Development (CTD) if AfCFTA opts to use enabling clause exception; or it should be notified to the Committee on Regional Trade Agreement if AfCFTA opts to use Article XXIV of GATT/WTO exception. This comment examines under which exception AfCFTA should notify its integration. I argue that it is better for AfCFTA to notify its integration under Article XXIV of GATT/WTO to the Committee on Regional Trade Agreement rather than under enabling clause to the Committee on Trade and Development.

\section{Key terms}

WTO $\cdot$ AfCFTA $\cdot$ Enabling Clause $\cdot$ Article XXIV Exception $\cdot$ Procedural requirements $\cdot$ Substantive requirements

\section{Suggested citation:}

Yehualashet Tamiru Tegegn (2020), 'AfCFTA's Notification Options to WTO: Enabling Clause or Article XXIV Exception', 14 Mizan Law Review 2: 357-373.

\footnotetext{
* Yehualashet Tamiru Tegegn (LL.B, LL.M). I am very grateful to Bereket Alemayehu and Yibeltal Azene for their comments and suggestions on the earlier draft. Email: yehuala5779@gmail.com ORCID: https://orcid.org/0000-0002-9347-7400

\section{Frequently used acronyms}

AfCFTA Africa Continental Free Trade Agreement

GATT General Agreement on Tariffs and Trade

OAU Organization of African Unity

RTAs Regional Trade Agreements

WTO World Trade Organization
} 


\section{Historical Background to AfCFTA}

The Organization of African Unity (OAU) was formed in $1963^{1}$ with the view to promote regional integration among African countries. ${ }^{2}$ Promoting unity and solidarity, to coordinate and intensify the coordination, to defend their sovereignty, to eradicate all forms of colonialism ${ }^{3}$ and to promote international cooperation were envisaged as the main purposes of the organization. ${ }^{4}$ In response to the economic crisis in Africa ${ }^{5}$, in 1980 the OAU came up with comprehensive developmental strategy called the Lagos Action Plan which stressed the need to have independent economy and selfreliance that can eventually lead to the formation of the Africa Economic Community in $2000 .^{6}$

The realization of this grand project was envisaged through the vehicle of regional economic community. ${ }^{7}$ The OAU heads of state meeting in 1991 adopted the treaty establishing the African Economic Community. ${ }^{8}$ As stipulated under Article 4(1) of the Treaty, one of the main objectives of the Economic Community is "to promote economic, social and cultural development and the integration of African economies in order to increase economic self-reliance and promote an endogenous and self-sustained development." This, inter alia, envisaged abolishing tariff (customs duties imposed on import and export) and non-tariff barriers among member states of regional economic communities. ${ }^{10}$

${ }^{1}$ The year 1960 is also called Africa's year of freedom since around 17 African countries got their independence in this Year. See 1960: The year of Independence available at https://www.france24.com/en/20100214-1960-year-independence (Accessed 15 April 2020)

${ }^{2}$ Marina Sharpe (2013), 'Organization of African Unity and African Union Engagement with refugee protection: 1963-2011', Africa Journal of International and Comparative Law, Vol. 21 p. 53

${ }^{3}$ This objective completed in 1990 when Namibia got its independence.

${ }^{4}$ See Article 3 of the Founding Charter of the Organization of African Union. The full version on the charter is available at: https://www.blackpast.org/global-africanhistory/primary-documents-global-african-history/founding-charter-organizationafrican-unity// (Accessed 15 April 2020)

5 Jane L. Parpart (1986), 'Women's rights and the Lagos Plan of Action', Human Rights Quarterly, Vol. 8, p. 180

${ }^{6}$ D. G. Anglin (1984), 'Independent Black Africa: Retrospective and prospect', International Law Journal, Vol. 39 p. 497

${ }^{7}$ Ibid

${ }^{8}$ See, Volume 3 of African Journal of International and Comparative Law(1991)

${ }^{9}$ Ibid

${ }^{10}$ Article 4(2)(d) of the Treaty established African Economic Community 
Currently, there are several regional integration initiatives in Africa ${ }^{11}$ which serve as a building block. However, they impeded the aspirations of integration because of multiple membership, ambitious targets and poor implementation. ${ }^{12}$ In 2001 the Constitutive Act of the African Union (AU) was adopted by the Assembly of Heads of Government of the then OAU. ${ }^{13}$ The Constitutive Act entered into force in the same year and the AU became fully operational and replaced the OAU. ${ }^{14}$ One of the main objectives of the $\mathrm{AU}$ is to accelerate socio-economic integration of the continent. ${ }^{15}$

In 2012 , the $18^{\text {th }}$ ordinary session of the Assembly of the heads of government of the AU agreed to establish a Continental Free Trade Area and launched formal negotiation in $2015 .{ }^{16}$ In reaching such milestone decision, the heads of government believe that the free trade area will boost trade between and among African countries. The summit concurrently adopted the Action Plan on Boosting Intra-Africa Trade (BIAT) which identified seven key clusters: trade policy, trade facilitation, production capacity, traderelated infrastructure, trade finance, trade information and factor market integration. ${ }^{17}$

2018 was another phenomenal year in terms of regional integration in Africa. In Kigali at the $10^{\text {th }}$ extraordinary session of the AfCFTA, three separate agreements were signed: the AfCFTA, the Kigali Declaration and

${ }^{11}$ COMESA (Common Market for Eastern and Southern Africa), EAC (Eastern Africa Community), ECCAS (Economic Community of Central African States), IGAD (Inter Governmental and Authority on Development), CEMAC (Economic Community of Central Africa States), UEMOA (West African Economic and Monitory Union WAEMU, MRU (Mano River Union), CEN-SAD (Community of Sahel-Saharan States), ECOWAS (Economic Community of Western Africa States), SADC (Southern Africa Developmental Community), UMA (Arab Maghreb Union) and WAMZ (West African Economic Institution)

12 Trudi Hartzenberg (2011), 'Regional integration in Africa', WTO Staff Working Paper ERSD-2011-14, p. 1

13 The Constitutive Act of the African Union, OAU Doc. CAB/LEG/23.15. The can be available at http://hrlibrary.umn.edu/africa/auconst-act2001.html (Accessed 15 April 2020)

14 Jonathan D. Rechner (2006), 'From the OAU to the AU: A normative shift with implication for peacekeeping and conflict management or just a name change', Vanderbilt Journal of Transnational Law, Vol. 39, p. 559

${ }^{15}$ Art. 3(c) and Article 17 of the Constitutive Act of the African Union, supra note 13

${ }^{16}$ See the official website of AU which is available at https://au.int/en/ti/cfta/about( accessed 16 April 2020)

${ }^{17}$ UN Economic Commission for Africa Action Plan for Boosting Intra-Africa Trade available at https://www.uneca.org/pages/action-plan-boosting-intra-africa-trade/ (Accessed 16 April 2020) 
the protocol on free movement of persons, right to residence and right to establishment. ${ }^{18}$ The agreement that established AfCFTA entered into force on 30 May 2019 after achieving the minimum number of ratification. On this submit alone, 44 out of the 55 African countries signed the AfCFTA. ${ }^{19}$ By August 16 2019, AfCFTA was signed by all African countries except Eritrea. This makes AfCFTA the biggest regional trade agreement in the world since the establishment of the WTO in $1995 .{ }^{20}$

The UNCTAD envisages the positive impact of AfCFTA in welfare gain, output and employment expansion. ${ }^{21}$ Although UNCTAD also predicts the possible losses of revenue from reduction of tariffs, in the long run AfCFTA will enhance intra-trade between and among African countries. ${ }^{22}$ AfCFTA is expected to enhance Africa's economic integration by creating a single market for goods and services which will be accompanied by free movement of persons. ${ }^{23}$ This process will culminate in the creation of a custom union which in turn leads to "an integrated, prosperous and peaceful Africa." 24

\section{Overview of the Nexus between Regional Trade Arrangements and WTO}

The big concern from the very start was how to reconcile the interests of the developed and developing countries in one legal system ${ }^{25}$ under the WTO,

18 TRALAC $10^{\text {th }}$ Extra Ordinary Session of the Assembly of the African Union on AfCFTA held in Kigali( 2018) :https://www.tralac.org/news/article/12865-10thextraordinary-session-of-the-assembly-of-the-african-union-on-afcfta-held-inkigali.html (Accessed 16 April 2020)

${ }^{19} \mathrm{H}$ Wasserman South Africa will be one of the biggest beneficiaries from the new African Free Trade Area (2018) available at https://www.businessinsider.co.za/sa-tobenefit-most-from-africa-free-trade-area-2018-3 (Accessed 16 April 2020)

${ }^{20}$ Sheila Kairu (2019), The AfCFTA, the benefits, the TBTs Challenges, the opportunities and the role of the ARSO. Available at https://www.arso-oran.org/theafcfta-the-benefits-the-tbts-challenges-the-opportunities-and-the-role-of-arso// accessed 16 April 2020/

${ }^{21}$ UNCTAD (2018), 'African Continental Free Trade Area: Challenges and opportunities on tariff reduction', UNCTAD Research Paper, No. 15. Available at https://unctad.org/en/PublicationsLibrary/ser-rp-2017d15_en.pdf (Accessed 16 April 2020)

${ }^{22}$ Ibid

${ }^{23}$ Article 3(a) of the Agreement Establishing the AfCFTA

${ }^{24}$ Article 3(a) cum Article 3(d) of the Agreement Establishing the AfCTA

25 Jennifer L. Stamberger (2003), 'The legality of conditional preferences to developing countries under the GATT enabling clause', Chicago Journal of International Law, Vol. 4 No. 2 p. 607 
and the latter constitute $75 \%$ of the WTO membership. One of the core principles of the WTO's system is the principle of non-discrimination which is embodied under two tools: national treatment ${ }^{26}$ and most-favoured nation standard of treatment. ${ }^{2728}$ Article 1 of the General Agreements on Tariffs and Trade (GATT) states that "... any advantage, favour, privilege or immunity granted by any Contracting Party to any product originating in or destined for any other country shall be accorded immediately and unconditionally to the like product originating in or destined for the territories of all other contracting parties." 29 This being the principle, the GATT/WTO has exceptions for this rule by way of enabling clause ${ }^{30}$ and Regional Trade Agreements (hereinafter RTAs). ${ }^{31}$

\subsection{Enabling clause}

At the inception of the GATT, there was neither an enabling clause nor Article XXIV exception; however, the need to have such clause was a bone of contention. For instance, in 1948 the USA requested waiver of the nondiscrimination principle to grant duty free treatment for Pacific Island. Likewise, Italy and Austria requested waiver to grant different treatment for Libya and Papua New Guinea respectively. ${ }^{32}$ Although there was no clear reason provided by Italy for such waiver, Austria made it clear that trade preference is an effective mechanism to enhance the economic growth of least developed countries. ${ }^{33}$

Furthermore, Austria made a point that developed nations are in a much better position than the free market principle to select products which suit to facilitate the economic growth of the least developed nations. ${ }^{34}$ Although

\footnotetext{
${ }^{26}$ Article 3 of GATT/WTO

${ }^{27}$ Article 1 of the GATT/WTO

${ }^{28}$ For more enlightened discussion on this point please see K Bagwell and W Staiger (1997), 'Reciprocity, non-discrimination and preferential agreement in the multilateral trade system', Working Paper 5932 National Bureau of Economic Research

${ }^{29}$ Article 1 of the GATT/WTO

${ }^{30}$ Article 1 of Differential and More Favoured Treatment, Reciprocity and Full Participation of Developing Countries

${ }^{31}$ Article 24 of the GATT/WTO

${ }^{32}$ Ibid

${ }^{33}$ Elisa Patterson (2005), 'Rethinking the Enabling Clause' Journal of World Investment and Trade, Vol. 6 No. 5 p. 733

${ }^{34}$ Ibid
} 
there were opposition and suspicion as to preference $\operatorname{trade}^{35}$, in 1979 the member states come up with a comprehensive agreement on differential and more favoured treatment, reciprocity and full participation of developing countries commonly known as "enabling clause". ${ }^{36}$ This was implemented through the Generalised System of Preference (GSP). ${ }^{37}$

The policy justification behind this clause is the need for leeway as a means to enhance the economic development of least developing countries and ultimately enhance trade liberalization. ${ }^{38}$ The need to have different treatment for developing countries is well recognized under paragraph two of the preamble of the establishment document of WTO which indicates that positive effort should be exerted to enable developing and least developing countries to secure fair share of participation in international trade. ${ }^{39}$ This is reaffirmed by the Doha Ministerial Declaration which states that "...we agree that special and differential treatment for developing countries shall be an integral part of all elements of the negotiations." 40

Enabling clause can be applied among developing countries on the one hand and between developing and developed countries on the other. ${ }^{41}$. Under Paragraph 2(a) of the enabling clause, the presence of two blocks of countries is contemplated: preference-granting countries (developed countries) and preference-receiving countries (developing countries). ${ }^{42}$

Generally, the type of preference given by developed countries to the developing world under the enabling clause should be generalized, nonreciprocal and non-discriminatory in nature. ${ }^{43}$ However, the general trend

35 The objection for preference system was mainly based on the premise tha such exception by way of elastic interpretation may end up swallowing the rule and undermine WTO system.

${ }^{36}$ The full version of this agreement is available at https://www.wto.org/english/docs_e/legal_e/enabling1979_e.htm( accessed 13 March 2020)

${ }^{37}$ Article 2(a) of the enabling clause

38 Stamberger, supra note 25 p. 733

${ }^{39}$ The full version of the established document is available at https://www.wto.org/english/docs e/legal e/04-wto.pdf (Accessed 13 March 2020)

${ }^{40}$ Doha Ministerial Declaration (2001) November 14. The full version of this document is available at https://www.wto.org/english/thewto_e/minist_e/min01_e/mindecl_e.htm (Accessed 13 March 2020)

${ }^{41}$ Paragraph two of the Enabling clause

${ }^{42}$ Patterson, supra note 33, p. 739

${ }^{43}$ This came from the 1971 waiver decision. See K Moss (2006), 'The consequences of the WTO appellate body decision in EC-Tariff preference, for the African Growth 
shows that developed nations usually embody conditions which the developing countries should comply to benefit from the preferential regime. For instance, many of US preference regimes to the benefit of developing countries are dependent upon conditions which range from human rights compliance to intellectual property protection. ${ }^{44}$ And the president of the US may revoke the special benefit at any time if a preference receiving country deviates from the condition set forth. ${ }^{45}$ This ultimately becomes contingent upon the political consideration of the preference giving country. ${ }^{46}$

Developing countries do not usually object such conditionality, even where various preference arrangements tend to be more of political than a legal issue. Developing countries want to keep their good relationship with donor countries and do not want to express their objection before the WTO Panel since "developing countries that receive preferences want to retain them, and developing countries that do not receive such preferences are fearful of jeopardizing their chances of receiving them in the future." ${ }^{47}$

However, India had challenged the condition and discriminatory preference given by the European Union alleging that it is contrary to the enabling clause. This occurred when European Union came up with five different types of generalized tariff preferences: general arrangement, special incentive arrangement for the protection of labour rights, special incentive arrangement for the protection of the environment, special arrangement for least developing countries, and special arrangement to combat drug production and trafficking. ${ }^{48}$

Opportunity Act and Sub-saharan Africa', New York University Journal of International Law and Politics, Vo. 38 No. 3 p. 688

${ }^{44}$ P. Sima-Eichler, J Tobin and M Busch, No no they can't take that away from me: why friends of the U.S are more likely to use the Generalized System of Preference (pdf) at 3. Available at http://www.petersimaeichler.com/uploads/5/6/5/0/56508149/why_friends_of_the_us_are_more_likely_to_u se the gsp.pdf (Accessed 16 April 2020). See also R Howse (2003), “India's WTO Challenge to Drug enforcement conditions in the European community generalized system of preferences: a little known case with major repercussion for 'political' conditionality in US trade policy”, Chicago Journal of International Law, Vol. 4 No.2

${ }^{45}$ Ibid

${ }^{46}$ K. Bagwell, C. Mavroidis and W. Staiger (2002), 'It's a question of market access', America Journal of International Law, Vol. 96 at 72

${ }^{47}$ Stamberger, supra note 25 p. 610

${ }^{48}$ See Article 1 of Council Regulation (EC) No. 2501/2001. This regulation is available at https://publications.europa.eu/en/publication-detail/-/publication/bd2cff5c-27c949ef-a6f9-3e9d41bc1d82/language-en (Accessed 16 April 2020) 
The general arrangement was open for all developing countries. ${ }^{49}$ However, the remaining tariff preferences were only for selected countries and for those that meet the different criteria $;{ }^{50}$ and India did not benefit from drug combating and trafficking arrangement. ${ }^{51}$ The Appellate body while reversing the finding of the panel on non-discrimination, stated that the preference giving country can determine the development, financial and trade need of developing countries based on individual country needs because to consider the need of developing countries collectively "is simply unrealistic to assume that such development will be in lockstep for all developing countries at once, now and for the future." ${ }^{52}$

Some argue that the enabling clause is the only applicable preference amongst developing countries. Under Paragraph 2(c), "Regional ${ }^{53}$ or global arrangements ${ }^{54}$ may be entered into amongst less-developed contracting parties for the mutual reduction or elimination of tariffs and, in accordance with criteria or conditions which may be prescribed by the Contracting Parties." Moreover, Paragraph 2(d) envisages "special treatment on the least developed among the developing countries in the context of any general or specific measures in favour of developing countries."

\subsection{The Exception under Article XXIV of GATT/WTO}

The other exception is Article XXIV of GATT/WTO. Various negative adjectives have been employed: extremely elastic, unusually complex, full of holes, full of ambiguity, vague absurdity, contradictory even mysterious. ${ }^{55}$

${ }^{49}$ See Article 7 of the Council Regulation (EC). Ibid.

${ }^{50}$ This is evident by the very title of the benefits. For instance special incentive for least developed countries only target least developed countries, special incentive arrangement for protection of labor rights put conditionality of labor rights to get the benefit.

${ }^{51}$ WTO DS246 European Communities-condition for the granting of tariff preferences to developing countries available at

https://www.wto.org/english/tratop_e/dispu_e/cases_e/ds246_e.htm (Accessed 16 April 2020)

${ }^{52}$ WTO Appellate body decision WT/DS246/AB/R (2004) Para. 160 page 65. The full version of this decision is available at https://view.officeapps.live.com/op/view.aspx?src=http\%3A\%2F\%2Fwww.wto.org\% 2Fenglish\%2Ftratop_e\%2Fdispu_e\%2F246abr_e.doc (Accessed 16 April 2020)

${ }^{53}$ This means those RTAs formed between member countries of the same geographical location like AfCFTA

${ }^{54}$ This means those RTAs formed between member countries of different geographical region like EU-China

${ }^{55}$ Kerry Chase (2006), 'Multilateralism compromised: the mysterious origins of GATT Article XXIV', World Trade Review, Vol. 5 No. 1 p. 1 
However, from the very start, GATT tolerates formation of customs union and free-trade areas in spite of Most Favoured Nation (MFN) principle. ${ }^{56}$

The USA had at an early stage, raised its concern that customs union and free trade areas arrangements need clarification. ${ }^{57}$ The US had firmly believed that customs union has the effect of trade diversion whereas Regional Trade Agreements (RTAs) have the contrary effect, until it eventually pursued a different course as it was expressed in the following official document: ${ }^{58}$

Customs Union creates a wider trading area, removes obstacles to competition, makes possible a more economic allocation of resources, and thus operates to increase production, and raise planes of living. A preferential system, on the other hand, retains internal barriers, obstructs economy in production, and restrains the growth of income and demand." 59 However, USA changed its policy stance when the then Secretary of State, Foster Dulles, said "... the United States has taken a different and generally favoured attitude, however, toward customs union and free trade areas....

Under Article XXIV of GATT/WTO we have customs union and free trade area exceptions. The close reading of Article XXIV of GATT reveals that RTAs can be custom unions, free trade areas and interim agreements. Customs union is when two or more independent countries adopt a common external tariff to third parties and substantially reduce the tariff between and among themselves. ${ }^{60}$ Free Trade Areas on the other hand emerge when two or more countries come together and substantially reduce the tariff between and among themselves with the view to facilitate trade; however each

56 Y. Devuyst and A. Serdarvic (2007), 'The World Trade organization and regional trade agreements: bridging the constitutional credibility gap', Duke Journal of Comparative and International Law, Vol. 18 p. 17

${ }^{57}$ Chase, supra note 55 p. 3

${ }^{58}$ Circular Airgram from the secretary of state to certain diplomatic mission(1986) at 450 as quoted by Devuyst and Serdarvic, supra note 56, p. 19

${ }^{59}$ C. Wilcox (1949), A Charter of World Trade p. 70 as quoted in Zakir Hafez (2003), 'Weak discipline: GATT Article XXIV and the emerging WTO Jurisprudence on RTAs', North Dakoto Law Review, Vol. 79 p. 882

${ }^{60}$ Article XXIV 8(a)(i) and (ii) of the GATT available at https://www.wto.org/english/tratop_e/region_e/region_art24_e.htm/ accessed 17 April 2020/ for more detailed and enlighten discussion please see P Steve(1996), Living in sin: Legal integration under the EC-Turkey customs union, European Journal of International Law, Vol. 7 No. 3 
country is allowed to retain their tariff rate to third parties. ${ }^{61}$ These two arrangements assume they will enter into force immediately after the conclusion of the agreement. ${ }^{62}$ However, under Article XXIV, members of GATT envisage the possibility of a gap between the conclusion of the agreement and entry into force of the same agreement and this is called interim agreement. ${ }^{63}$

Generally speaking, Article XXIV has both substantive and procedural requirements. ${ }^{64}$ It imposes two substantive requirements. According to the first substantive requirement indicated under Article XXIV(5), the general incident of tariff should not be more restrictive or higher than before the formation of RTAs; and the second substantive requirement obliges contracting parties to eliminate tariff with respect to "substantially all the trade between the constituent territories." $" 65$ The procedural requirements are: notification and negotiation with third parties. Any contracting party intending to enter into customs union or free trade agreements should notify and make available necessary information to the WTO. ${ }^{66}$

The purpose of notification is to enhance transparency and assist the Committee on Regional Trade agreement examine its compliance with Article XXIV ${ }^{67}$ In principle, the general incident on tariff should not be higher or more restrictive than what was before the formation of RTAs for third parties. ${ }^{68}$ However, if the RTAs increase the tariff contrary to Article II, then they should provide compensatory adjustment. ${ }^{69}$ As envisaged under Article XXIV, negotiation should be conducted in "good faith with the view to achieving mutually satisfactory compensatory adjustment.",70

${ }^{61}$ Article XXIV 8(b) of GATT for more detail discussion please see P Hilpold (2003), Regional Integration according to Article XXIV GATT-between Law and Politics, Max Planck Yearbook of United Nations Law

${ }^{62}$ Hafez, supra note 59 p. 886

${ }^{63}$ Article XXIV 8

${ }^{64}$ WTO (2003), Legal note on regional trade arrangements under the enabling clause

${ }^{65}$ Article XXIV (a)(i) cum (b)

${ }^{66}$ Article XXIV 7(a) of GATT

67 WTO WT/L/671 Transparency mechanism for regional trade agreements(2006) available at http://ptadb.wto.org/docs/pta_transparency_rta_en.pdf (Accessed 17 April 2020)

${ }^{68}$ Article XXIV 5(a) cum (b)

${ }^{69}$ Article XXIV 6

${ }^{70}$ Understanding on the interpretation of Article XXIV of the General Agreement on Tariffs and Trade 1994 available at https://www.wto.org/english/tratop_e/region_e/region_art24_e.htm/ accessed 17 March 2020/ 


\section{The Better Option for AfCFTA's Notification to WTO}

I argue that that AfCFTA will be better off if it is notified under Article XXIV of GATT/WTO to the Committee on RTAs rather than invoking the enabling clause to the Committee on Trade and Development (CTD) as highlighted in the following sub-sections.

\subsection{The opportunity for WTO member and non-member states}

The close reading of Paragraph 2(c) of the enabling clause reveals that such regional or global arrangement should be ".... amongst developing countries contracting parties..." The wording of Paragraph 1 and other provisions of Paragraph 2 does not have any qualification but simply discuss developing countries.

On the contrary, Paragraph 2(c) requires the member to be contracting party, i.e. a member state of GATT/WTO. ${ }^{71}$ As per Article 31 of the Vienna Convention on the Law of Treaty (hereinafter VCLT), ${ }^{72}$ a treaty should be construed in line with the very purpose it wants to achieve. The prohibition of non-WTO members to join and form RTAs under the enabling clause is very consistent with the purpose of enabling clause as reflected under Paragraph $1 .^{73}$

This presupposes all members of such arrangement to be members of the WTO at the same time. ${ }^{74}$ Among members of the AfCFTA, there are a lot of non-WTO members, such as Ethiopia, and this reality cancels out the possibility of registering under the enabling clause. However, under Article XXIV of the WTO, RTAs can be formed between members and nonmember states of the WTO. Paragraph 4 of Article XXIV states that “... Free Trade Area should be to facilitate trade between constituent territories. ..." Unlike the enabling clause, there is no qualification that the arrangement should be between contracting parties (i.e., between WTO members). ${ }^{75}$

${ }^{71}$ Louise E. Mossner (2014), 'The WTO and regional trade: a family business? The WTO compatibility of regional trade agreements with non-WTO-members', World Trade Review p. 646

${ }^{72}$ Article 31(2) of VCLT state that "The context for the purpose of the interpretation of a treaty shall comprise, in addition to the text, including its preamble and annexes ' 24 ' at 309

${ }^{73}$ C. Won-Mon and L. Youg-Shik (2012), 'Facilitating preferential trade agreement between developed and developing countries: a case for 'enabling' the enabling clause' Minnesota Journal of International Law, Vol. 21 No. 1 p. 7

${ }^{74}$ Ibid

${ }^{75}$ See the above discussion on enabling clause 
Furthermore, as per purposive rule of interpretation, the RTAs envisaged under WTO are meant to enhance regional grouping which is believed to be the building block for further trade liberalization. Thus, this is possible when RTA is formed between member and non-members. ${ }^{76}$ This is well supported by the practical application in the sense that countries such as the USA, China and Russia conclude various RTAs with non-WTO member states which is notified under Article XXIV ${ }^{77}$ European Union is also a party to 11 RTAs with non-WTO members. ${ }^{78}$

It is to be noted that even the most vehement objector of RTAs between member and non-WTO member states, Mossner, accepts the fact that most of the countries which are yet to accede to WTO (around 50 countries) are developing countries and hence concluding RTAs with non-WTO member states will enhance their economy and bring trade liberalization in the long run. ${ }^{79}$ One can thus safely conclude that AfCFTA should notify under Article XXIV rather than the enabling clause.

\subsection{The features of tariff rate reduction under the two options}

As per Paragraph 3 of the enabling clause exception, for such arrangement to be qualified under enabling clause, the member states should eliminate or reduce the tariff rate between themselves. In comparison to substantial elimination of all trade barriers requirements under Article XXIV, ${ }^{80}$ the requirement under enabling clause is very loose in such a way that reduction of tariff even in a de minimis fashion will qualify as tariff reduction. To put it differently, this arrangement does not fully enhance trade liberalization. For instance, under South Asian Free Trade Agreement (SAFTA) ${ }^{81}$, which was notified to WTO under enabling clause for its establishment, reduction of only $0 \%-5 \%$ tariff within ten years is envisaged. ${ }^{82}$

\footnotetext{
${ }^{76}$ Marceau and others (2001), 'When and how is a regional trade agreement compatible with the WTO?' Legal Issues of Economic Integration, Vol. 28, No.3 p. 303

${ }_{77}^{7}$ Mossner, supra note 71 p. 635

78 The main reason is that such arrangement will help EU to reduce tariff, and it is believed to be a good completion strategy in the major market. See European Commission annex to global Europe competing in the world: a contribution to the EU's growth and job strategy (2016) at 16

${ }^{79}$ Id. p. 635

${ }^{80}$ Article 24 of GATT

${ }^{81}$ The member states are Bangladesh, Bhutan, India, Maldives, Nepal, Pakistan and Sri Lanka. This information is available at https://aric.adb.org/fta/south-asian-free-tradearea (Accessed 13 May 2020)

82 The full version is available at https://aric.adb.org/fta/south-asian-free-trade-area (Accessed 13 May 2020)
} 
On the other hand, the agreement between the government of the Islamic Republic of Pakistan and the Government of Malaysia for a closer Economic Partnership was notified to WTO under enabling clause, and it shows insignificant tariff reduction. ${ }^{83}$ On the contrary, one of the substantive requirements under Article XXIV is that member parties should eliminate substantially all trade barriers between themselves but without defining what "substantially all trade" means. Article XXIV ${ }^{84}$ does not say anything about the threshold regarding what is meant by 'substantial'. In the absence of a clear-cut figure or conceptual framework in the WTO, we are compelled to look for the answer from other areas.

As per Article 38(d) of ICJ Statute, decision of court is one of the sources of international law. ${ }^{85}$ Accordingly, the appellate body under Turkey-Textile case ruled that "substantially all trade is not the same as all trade and also is something considerably more trade than some trade." 86 The proposed definition under the Treaties that established EEC and Atomic Energy Community (commonly known as ECT) state that "a free trade should be considered as having achieved for substantially all the trade when the volume of liberalized trade reached $80 \%$ of total trade. $"{ }^{" 87}$

Unlike many other similar concepts, ${ }^{88}$ one typical feature of Free Trade Areas like that of AfCFTA is that member states should abolish all types of trade barriers while they can still maintain external tariff to non-member states. ${ }^{89}$ Although there is no clear-cut answer to what is 'substantial', the expectation of tariff reduction under Article XXIV is clearly higher than what the enabling clause envisages. Under Article 4 of the AfCFTA establishment treaty, it is indicated that one of the objectives is to

${ }^{83}$ The full version of this agreement is available at https://wits.worldbank.org/GPTAD/PDF/archive/Malaysia-Pakistan.pdf (Accessed 13 April 2020)

${ }^{84}$ Please see Understanding on the interpretation of Article XXIV of the General Agreement on Tariffs and Trade 1994. The full version of this document is available at https://www.wto.org/english/docs_e/legal_e/10-24_e.htm (Accessed 14 April 2020)

85 Please see ICJ statute which is available at https://www.icj-cij.org/en/statute (Accessed 17 July 2020)

${ }^{86}$ Turkey-restrictions on imports of textile and clothing products WT/DS34/AB/R( 22 October 1999) Paragraph 48. The full version of the decision of appellate body is accessible at https://www.wto.org/english/tratop_e/dispu_e/cases_e/ds34_e.htm (Accessed 14 April 2020)

${ }^{87}$ Won-Mog and Yong-shik, supra note 73 p. 3

${ }^{88}$ Generally speaking there are five types of regional trade preferences: preferential arrangement, free-trade area, custom union, economic union and political union

${ }^{89}$ Marceau and others, supra note 76 
progressively eliminate tariff and non-tariff barriers which can eventually lead to the formation of customs union. To enhance trade liberalization by removing tariff barriers 'substantially' and to realize this objective, AfCFTA should be notified under Article XXIV than the enabling clause.

\subsection{Membership opportunities for least developed and other states}

The rationale behind Paragraph 2(c) of the enabling clause is to enhance protection for a specific group, i.e., less developed countries. ${ }^{90}$ Some argue that the phrase less-developing countries under Paragraph 2(c) of the enabling clause can be interpreted as synonymous with developing countries. ${ }^{91}$ However, this argument is not plausible because the enabling clause is the exception to the general rule, and it should be construed very narrowly. ${ }^{92}$ Thus, all members of enabling clause arrangement should be least developed countries. This implies that if one of the member states is not among the least developed countries, the agreement will not qualify under the enabling clause, even if all of the member states are members of the WTO.

As things stand, the Republic of South Africa, ${ }^{93}$ for example, which has signed AfCFTA, ${ }^{94}$ does not seem to fall under this category of least developed countries. On the other hand, there is no such requirement under Article XXIV exception. Therefore, AfCFTA should be notified under Article XXIV exception because developed, developing and least developing countries can, without distinction, utilize Article XXIV exception.

\subsection{Binding commitment beyond mere aspiration}

The first two lines of paragraph 2(c) of the enabling clause reveal that contracting parties enter into such arrangement "for the mutual reduction or elimination of tariff." This is more of aspiration than obligatory, in the sense that the main thing expected from the contracting parties is their intention to

${ }^{90}$ Won-Mog Choi (2005), 'Legal Problem of Making Regional Trade Agreements with non-WTO Member States', Journal of International Economic Law, Vol. 8 p. 855

${ }^{91}$ Ben Sharp (2010) , 'Comparing preferential trade agreement scrutiny under GATT Article XXIV and the enabling clause: Lessons learned from the Gulf cooperation council', Manchester Journal of International Economic Law, Vol. 7, No. 1 p. 61

92 On the narrow rule of interpretation, see H Lauterpacht (1949), 'Restrictive interpretation and the principle of effectiveness in the interpretation of treaties', British Yearbook of International Law, Vol. 26

93 See https://www.worldbank.org/en/country/southafrica/overview (Accessed 17 April 2020)

${ }^{94}$ For more information about this please see https://www.tralac.org/news/article/13216sa-signs-african-continental-free-trade-area-agreement.html/ accessed 18 April 2020/ 
reduce or eliminate tariff between and among themselves. ${ }^{95}$ In other words, although the application is arduous, such arrangement can still be qualified under the enabling clause.

However, such arrangement will not benefit AfCFTA because what is needed is a binding commitment rather than mere aspiration. On the contrary, Article XXIV(8)(b) embodies strongly obligatory words such as "substantially all the trade". I argue that the best option for Africa that has leaders and tendencies who are very protectionist, is by putting in place binding and mandatory provision rather than aspiration clause. Therefore, the viable option for Africa, from a pragmatic point of view, is notifying AfCFTA to WTO under Article XXIV rather than enabling clause.

\subsection{Rules of origin as protection against trade deflection}

The last line of Paragraph 2(c) of the enabling clause requires member states to reduce or eliminate non-tariff measures on "products imported from one another." This provision does not have any indication of rule of origin, and this gap will be counterproductive because it exposes member states to problems such as tariff gap and trans-shipment/trade deflection. ${ }^{96}$

If a number one coffee producer company in a non-member state exports its product to the subsidiary company in a member state which maintains lower tariff for non-member states, the subsidiary company in a non-member country will, in effect, export the coffee without adding any value to countries which have reduced their tariff for member states. The difference between the tariff to be paid for a given product had there been rules of origins and the tariff actually paid is called tariff gap and the fact that a company in a non-member state accesses a market through the instrumentality of a member state of RTAs is called trans-shipment or trade deflection. Thus, if AfCFTA is registered under the enabling clause, it can be susceptible to free riding which adversely affects its effectiveness.

On the other hand, Article XXIV seems to have provisions which deal with rules of origin. ${ }^{97}$ Generally, under the WTO system, ROs can be

\footnotetext{
${ }^{95}$ Supra note 93 at 64
}

${ }^{96}$ William E. James (2010), 'Rules of origin in emerging Asia Pacific Preferential trade agreements: will PTAs promote trade and development?' Working paper series No. 19 Asia-pacific Research and Training Network on Trade, p. 3. Also see N Harilal and L Beena (2003), 'The WTO agreement on rule of origin: implications for South Asia', Working Paper No. 352, p. 12

97 J. Garray and D. Lombaerde (2005) , 'Preferential rules of origin: EU and NAFTA regulatory Models and the WTO', Journal of World Investment and Trade, Vol. 6 p. 990 
broadly classified into non-preferential and preferential ROs. Nonpreferential ROs are designed by each member country of the WTO but not party to RTAs whereas preferential ROs are those which emanate from RTAs. ${ }^{98}$ Although there is no explicit mention of ROs under Article XXIV of the GATT, a close reading of Article XXIV(5) and (8) indicate the implicit recognition of the concept. Paragraph 8(a) makes reference to "... products originating in such territories. ..." Moreover, the words "... broken down by WTO country of origin...." in Paragraph (5)(2) are relatively clear. Thus, notification of AfCFTA under Article XXIV can address the problem of trade deflection or trans-shipment.

\section{Concluding Remarks}

The need to have regional economic integration was one of the pressing demands to bring economic development and enhance intra-Africa trade since the formation of OAU. This was well reflected under the OAU Constitutive Act. In 1991, the OAU established the African Economic Community as a suitable platform for the formation of various sub-regional economic blocks. However, the proliferation of building blocks, poor implementation and double even triple membership have impeded its effectiveness. After the formation of AU, however, African countries have expressed their commitment to form the largest continental free trade area in the world (effective May 2019) although its effectiveness is yet to be seen.

The AfCFTA is meant to operate under the umbrella of the WTO and hence should comply with both the substantive and procedural requirements of the WTO. Although the WTO legal system upholds the principle of nondiscrimination in international trade, there is also some 'breathing space' by way of exceptions. The most notable exceptions are the enabling clause and Article XXIV exception that deviate from the principle of Most-favouredNation Treatment and established free trade areas. With the view to secure transparency and compliance, one of the procedural requirements is that the contracting parties should notify and provide relevant documents to WTO's Committee on Trade and Development or to WTO's Committee on Regional Trade Agreement. Although AfCFTA can be notified to WTO in either exceptions, it will be beneficial to make the notification under Article XXIV exception to the Committee on Regional Trade Agreement.

${ }^{98}$ Ibid 